\title{
Pengaruh Koagulan PAC dan Tawas Terhadap Surfaktan dan Kecepatan Pengendapan Flok Dalam Proses Koagulasi Flokulasi
}

\author{
Elvis Umbu Lolo ${ }^{1 *}$, Yonathan Suryo Pambudi ${ }^{2}$, Richardus Indra Gunawan ${ }^{3}$, Widianto ${ }^{4}$ \\ ${ }^{1,2,3,4}$ Prodi Teknik Lingkungan, Fakultas Teknik, Universitas Kristen Surakarta \\ Jl Robert Wolter Monginsidi No.36-38 Margoyudan Surakarta \\ *Korespondensi email: eumbulolo@yahoo.co.id
}

Diterima: 12 September 2020

Disetujui: 26 September 2020

\begin{abstract}
Surfactants are compounds that make up deterjents, which if deterjent is dumped into the river it will cause pollution. In the province of West Java, river water and receiving water bodies, based on the results of the study, showed moderate to severe pollution by wastewater containing deterjents. The results showed that the PAC coagulant and alum has a small effect on the decrease in surfactant and floc velocity settling, where the decrease in surfactant in the rainy season for PAC coagulant is $49.51 \%$ and alum coagulant $40.73 \%$. While in the dry season the decrease in surfactant with PAC coagulant $41.06 \%$ and alum coagulant $31.10 \%$. Then the floc velocity settling was measured to explain the correlation of surfactant decline, and the results obtained for the rainy season floc velocity settling with PAC coagulant was $0.80 \mathrm{~cm} /$ minute and alum was $0.27 \mathrm{~cm} /$ minute. Whereas in the dry season with the PAC coagulant the floc velocity settling was $0.91 \mathrm{~cm} /$ minute and the alum coagulant was $0.31 \mathrm{~cm} /$ minute. The results of quantitative regression analysis with the SPSS statistical test showed that the H0 hypothesis was accepted, that the coagulant had no effect on surfactant reduction and floc velocity settling.
\end{abstract}

Keywords: flocculation, coagulation, river water, surfactants, floc velocity settling

\begin{abstract}
Abstrak
Surfaktan merupakan senyawa penyusun deterjen, dimana jika deterjen dibuang ke sungai akan menyebabkan pencemaran. Di provinsi Jawa Barat, air sungai dan badan air penerima berdasarkan hasil penelitian menunjukkan pencemaran skala sedang sampai berat oleh air limbah yang mengandung deterjen. Koagulasi Flokulasi merupakan proses penting dalam pengolahan air minum, karena dengan proses ini surfaktan akan direduksi dengan memakai bahan kimia yang disebut koagulan.Penelitian ini dilakukan dalam skala lapangan dan laboratorium, dengan prinsip scale down dengan alat jart test.Hasil penelitian menunjukkan koagulan PAC dan tawas memiliki pengaruh yang kecil terhadap penurunan surfaktan dan kecepatan pengendapan flok, dimana penurunan surfaktan pada musim hujan untuk koagulan PAC sebesar 49,51\% dan koagulan tawas 40,73\%.Sedangkan pada musim kemarau penurunan surfaktan dengan koagulan PAC $41,06 \%$ dan koagulan tawas 31,10\%. Kemudian Kecepatan pengendapan flok diukur untuk menjelaskan korelasi penurunan surfaktan, dan diperoleh hasil untuk musim hujan kecepatan pengendapan flok dengan koagulan PAC sebesar $0,80 \mathrm{~cm} /$ menit dan tawas sebesar $0,27 \mathrm{~cm} /$ menit.Sedangkan pada musim kemarau dengan koagulan PAC kecepatan pengendapan floknya $0,91 \mathrm{~cm} /$ menit dan koagulan tawas sebesar $0,31 \mathrm{~cm} / \mathrm{menit}$. Hasil analisa kuantitatif regresi dengan uji statistik SPSS menunjukkan bahwa hipotesis H0 diterima yaitu koagulan tidak mempunyai pengaruh terhadap penurunan surfaktan dan kecepatan pengendapan flok.
\end{abstract}

Kata kunci: air sungai, koagulasi flokulasi, kecepatan pengendapan flok, surfaktan

\section{Pendahuluan}

Pencemaran Sungai di Propinsi Jawa Barat meningkat dan belum memperlihatkan adanya penurunan yang berarti. Pencemaran air sungai dan permukaan lainnya telah berada pada ambang batas yang tidak hanya membahayakan bagi kesehatan masyarakat akan tetapi juga telah mengakibatkan kemampuan memperbaiki diri secara alami dan keseimbangan ekosistem Daerah Aliran Sungai menjadi menurun [1]. Laju kerusakan DAS tersebut akibat Pencemaran air limbah Industri dan rumah tangga. Di Propinsi Jawa Barat Terdapat 203.419 industri besar, sedang dan menengah [2]._Hampir sebagian besar dari industri tersebut membuang air limbah industrinya ke sungai. 
Terdapat 7 (tujuh) daerah aliran sungai (DAS) besar di Propinsi Jawa Barat yaitu Citarum, Ciliwung, Cisadane, Cileungsih, Cilamaya, dan DAS Cimanuk dimana semuanya mengalami pencemaran berat [3]. Demikian juga hampir 70\% air limbah rumah tangga juga dibuang ke sungai. Salah satu elemen utama dalam air limbah adalah adanya surfaktan. Surfaktan ketika masuk dalam perairan sungai tidak mudah terurai, sehingga senyawa ini akan berada didalam sungai dalam periode yang lama. Ketika air sungai digunakan sebagai sumber air baku dalam pengolahan air minum, surfaktan juga akan sulit terurai dalam sistem pengolahan yang lengkap termasuk proses koagulasi flokulasi. Menurut ref. [4] sisa bahan surfaktan yang terdapat dalam deterjen dapat membentuk klorobenzen pada proses klorinasi pada proses pengolahan air minum PDAM, senyawa ini bersifat toksik yang membahayakan kesehatan.

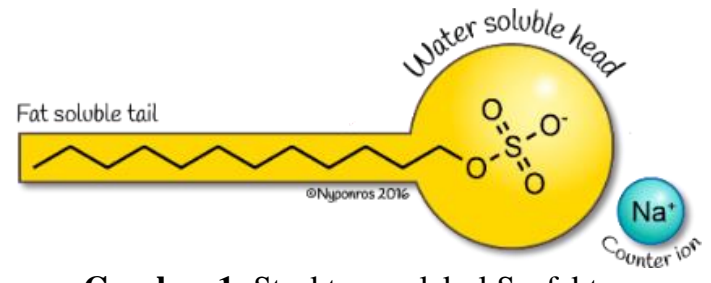

Gambar 1. Struktur molekul Surfaktan Sumber: Ref. [5]

Surfaktan yang sering dipergunakan dalam pembuatan sabun atau deterjen adalah Surfaktan anionik. Surfaktan anionik memiliki gugus alkil (umumnya C9-C15) atau garam dari sulfonat atau sulfat berantai panjang dari Natrium ( $\mathrm{RSO}_{3}{ }^{-} \mathrm{Na}^{+}$dan $\mathrm{ROSO}_{3}{ }^{-} \mathrm{Na}^{+}$) yang berasal dari derivat minyak nabati atau minyak bumi (fraksi parafin dan olefin). Surfaktan anionik adalah kelompok yang paling banyak digunakan dimasyarakat khususnya untuk proses pencucian baju rumah tangga maupun industri laundry [6].

Dalam pengolahan air minum skala lengkap yang dimiliki PDAM, surfaktan belum bisa dihilangkan dengan sempurna.Permasalahannya karena dalam proses koagulasi flokulasi dalam pengolahan air minum di PDAM koagulasi flokulasi hanya menggunakan prinsip hidrolis. Dengan teknik ini proses destabilisasi partikel koloid tidak maksimal terjadi karena pengaturan putaran pengaduk tidak dapat diatur untuk mengantisipasi tingkat kekeruhan yang berfluktuasi. Hal ini yang menyebabkan surfaktan tidak dapat direduksi dengan sempurna. Terdapat beberapa metode yang dapat digunakan untuk menurunkan kadar surfaktan, antara lain filtrasi, proses fotokatalisis, koagulasi dan adsorpsi [7].

Koagulasi dan flokulasi merupakan proses yang penting dalam pengolahan air bersih, karena dengan proses ini partikel koloid penyebab kekeruhan yang stabil dibuat menjadi tidak stabil. Partikel koloid antara lain, yaitu tanah liat, lumpur, virus, bakteri, asam fulvat dan humus, mineral antara lain: asbes, silikat, silika, dan partikel radioaktif, dan partikel organik, termasuk surfaktan. Dengan adanya pencemaran air sungai oleh surfaktan, akan mempengaruhi kinerja proses koagulasi flokulasi. Koagulasi adalah pengadukan cepat di mana bahan kimia (koagulan) ditambahkan ke air, yang menyebabkan pengurangan kekuatan yang cenderung membuat partikel koloid terpisah karena partikel koloid dalam sumber air berada dalam kondisi stabil [8].

Flokulasi adalah pengadukan lambat yaitu terjadi proses pembentukan flok-flok kecil (proses koagulasi) dengan flok-flok yang berukuran besar sehingga mudah diendapkan [9]. Partikel koloid merupakan partikel diskrit yang terdapat dalam suspensi air baku, dan partikel inilah yang merupakan penyebab utama kekeruhan [10]. Koagulan adalah bahan kimia sintetis yang digunakan untuk mengolah air bersih dan air limbah.koagulan yang digunakan dapat dibedakan menjadi polimer anorganik dan polimer alami [11].

Koagulan PAC adalah polimer aluminium seperti tawas dimana memiliki unsur klorida. PAC formula $\mathrm{Al}_{n} \mathrm{Cl}_{(3 \mathrm{n}-\mathrm{m})}(\mathrm{OH})_{\mathrm{m}}$. PAC yang sering dipakai pada pengolahan air yakni $\mathrm{Al}_{12} \mathrm{Cl}_{12}(\mathrm{OH})_{24}$. Koagulan PAC menghasilkan proses olahan yang lebih baik dibandingkan dengan koagulan yang lainnya.[12].PAC digunakan untuk mengurangi kebutuhan akan penyesuaian $\mathrm{pH}$ untuk pengolahan, dan digunakan jika $\mathrm{pH}$ badan air penerima lebih tinggi dari 7,5 [10]. Selain Poly Aluminium Chloride (PAC) terdapat juga koagulan lain yang sering dipergunakan dalam pengolahan air yaitu tawas. Tawas memiliki rumus molekul $\left(\mathrm{Al}_{2}\left(\mathrm{SO}_{4}\right)_{3} \mathrm{xH}_{2} \mathrm{O}\right.$ dimana $\mathrm{x}=14,16$. Koagulan tawas sering dipergunakan dalam pengolahan air bersih karena harganya murah jika dibandingkan dengan koagulan lain yang ada dipasaran [10].

Menurut ref. [6] proses koagulasi flokulasi air limbah laundry dengan koagulan PAC dapat menurunkan parameter deterjen dengan efisiensi penurunan BOD dan COD sebesar 11,57\% dan 78,57\%. Demikian juga pengolahan air permukaan dengan koagulan tawas menghasilkan penurunan surfaktan 
7,6\% [13]. Sedangkan dalam evaluasi penggunaan kembali lumpur tawas untuk koagulasi air limbah industry mengandung surfaktan anionik efisiensinya 95,4\% [14]. Selanjutnya dalam pengolahan air limbah laundry dengan koagulan tawas memberikan efisiensi pengolahan surfaktan sebagai MBAS sebesar $28 \%$ [15].

Informasi tentang penurunan surfaktan dalam air sungai dan kecepatan pengendapan flok dengan proses koagulasi flokulasi belum ada kajian dan penelitian serta belum dijelaskan secara mendetail.Oleh karena belum ada penelitian sehingga dilakukan penelitian untuk mendapatkan pengaruh koagulan terhadap surfaktan dan kecepatan pengendapan flok setelah melalui proses koagulasi flokulasi.Tujuan penelitian ini adalah untuk mengetahui pengaruh koagulan PAC dan tawas terhadap surfaktan dan kecepatan pengendapan flok dalam proses koagulasi flokulasi pada musim hujan dan kemarau pada sumber air baku sungai di Provinsi Jawa Barat.

\section{Metodologi Penelitian}

\section{Tempat dan Waktu Penelitian}

Penelitian ini mengambil sampel air sungai utama yang tersebar di Provinsi Jawa Barat. Pengambilan sampel air sungai dilakukan pada musim hujan dan musim kemarau. Pengambilan sampel air sungai pada musim hujan dilakukan pada bulan Januari sampai April 2006, sedangkan pada musim kemarau dilakukan pada bulan Juni sampai dengan bulan Oktober 2006. Sementara itu untuk uji laboratorium dilakukan di laboratorium Teknik Lingkungan ITB Bandung.

\section{Alat dan bahan}

Peralatan yang digunakan dalam penelitian ini adalah $\mathrm{pH}$ meter (Mettler-Toledo $\mathrm{MP}_{220}$ ), stop-watch (Seiko), UV-VIS spectrofotometer (Hitachi U-2001 UV), timbangan analitik (Shimadzu Libror AEG 220), jart test (Stuart Scientific SW6), separator tunnel (Pyrex), $\mathrm{K}_{2} \mathrm{PtCl}_{6}$ (Merck), $\mathrm{NaOH}$ kristal, tawas $\left[\mathrm{Al}_{2}\left(\mathrm{SO}_{4}\right)_{3} 18 . \mathrm{H}_{2} \mathrm{O}\right] \mathrm{pa}$, poly aluminium chloride (PAC) pa, methylene blue (Merck), chloroform $\left(\mathrm{CHCl}_{3}\right)$ (Merck), $\mathrm{NaH}_{2} \mathrm{PO}_{4} \mathrm{H}_{2} \mathrm{O}$ (Merck), aquades, kapas (bebas minyak), metanol, dan $\left(\mathrm{CH}_{3} \mathrm{OH}\right)$. Salah satu alat yang digunakan dalam penelitian dapat dilihat pada Gambar 2.

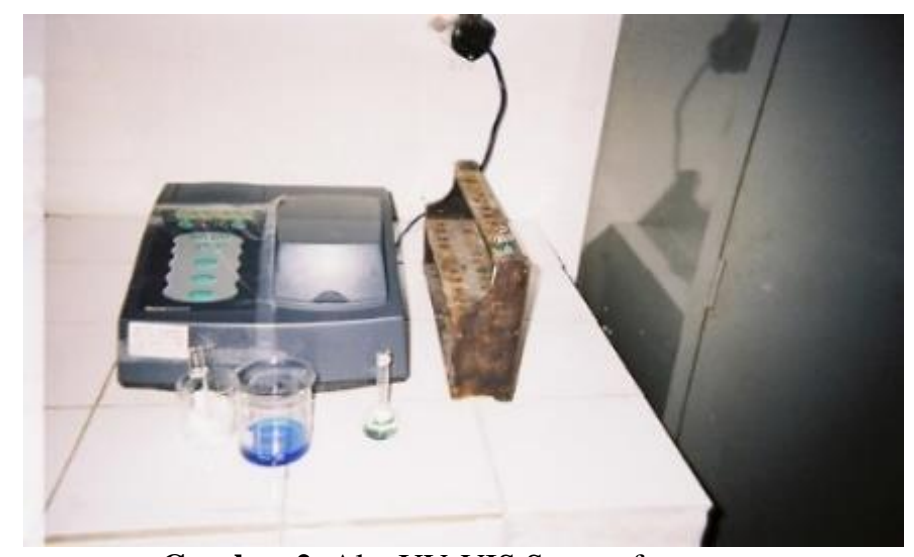

Gambar 2. Alat UV-VIS Spectrofotometer

Sumber: Dokumentasi pribadi

Bahan yang dipakai yaitu : $\mathrm{NaOH}$ kristal, tawas $\left[\mathrm{Al}_{2}\left(\mathrm{SO}_{4}\right)_{3} 18 . \mathrm{H}_{2} \mathrm{O}\right]$ pa, poly aluminium chloride (PAC) pa, methylene blue (Merck), chloroform $\left(\mathrm{CHCl}_{3}\right.$ ) (Merck), $\mathrm{NaH}_{2} \mathrm{PO}_{4} \mathrm{H}_{2} \mathrm{O}$ (Merck), aquades, kapas (bebas minyak), metanol, dan $\left(\mathrm{CH}_{3} \mathrm{OH}\right)$

\section{Prosedur}

a. Koagulasi Flokulasi

Jar test merupakan peralatan dan metode standar yang umum digunakan untuk menentukan dosis optimum yang dibutuhkan untuk mengolah air baku tertentu, yang sampai saat ini masih dipergunakan. Jar test juga merupakan model sederhana proses koagulasi flokulasi. Pelarutan koagulan dilakukan melalui dua tahap, yaitu pengadukan cepat ( 1 menit, $100 \mathrm{rpm}$ ) dan pengadukan lambat untuk membentuk flok-flok (10 menit, $60 \mathrm{rpm})$. Setelah proses koagulasi flokulasi dilanjutkan dengan proses pengendapan mikroflok dan makroflok. Dosis optimum koagulan ditentukan berdasarkan, ukuran flok yang lebih besar dan kecepatan flok tersebut mengendap di dasar beker gelas. 


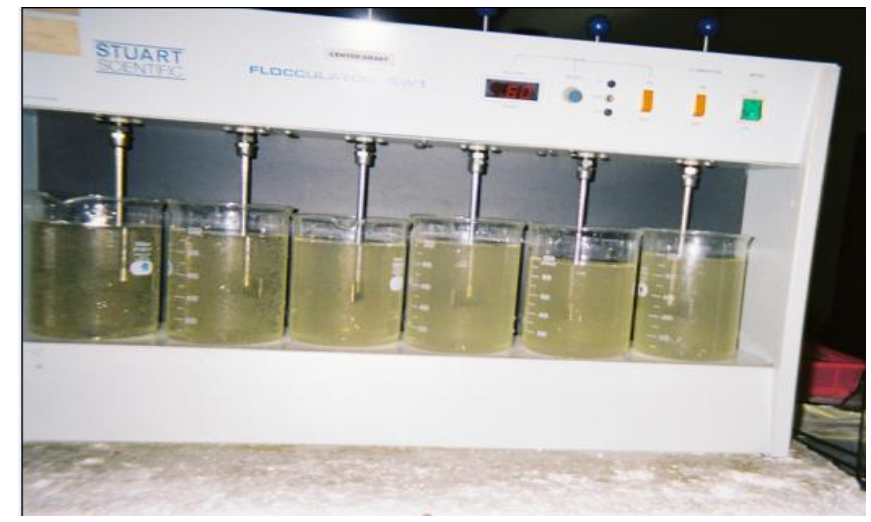

Gambar 3. Alat jar test

Sumber: Dokumentasi pribadi

\section{b. Pembuatan Kurva Kalibrasi LAS sebagai MBAS}

Kurva kalibrasi dibuat sebagai dasar pengukuran konsentrasi surfaktan dalam air sungai. Larutan standar MBAS dibuat dari larutan induk natrium lauril sulfat. Senyawa ini dipilih sebagai senyawa untuk larutan standar karena merupakan jenis surfaktan anionik yang banyak digunakan pada deterjen komersial. Kurva kalibrasi merupakan grafik yang menyatakan hubungan antara konsentrasi larutan standar dengan hasil pembacaan absorbansi larutan, yang hasilnya merupakan garis lurus [16]. Pengukuran dengan metoda ini didasarkan pada prinsip penangkapan ion surfaktan oleh kation methylen blue membentuk pasangan ion (ion pair formation). Kemudian pasangan ion ini di ekstraksi dengan chloroform $\left(\mathrm{CHCl}_{3}\right)$. Larutan ekstraksi tersebut membentuk warna biru yang kemudian dapat diukur adsorbannya dengan spectrophotometer pada panjang gelombang $\lambda 652 \mathrm{~nm}$. Persiapan kurva kalibrasi dimulai dengan menyiapkan 10 buah labu 1 liter, masukan kedalam tiap labu dengan larutan standar LAS masing-masing 0,1,3,5,7,9,11,13,15, dan $20 \mathrm{ml}$, tergantung dari range konsentrasi yang akan diukur. Pengukuran absorban dan hasil grafik hubungan dari absorban dengan konsentrasi LAS dapat dilihat pada Gambar 4 [17].

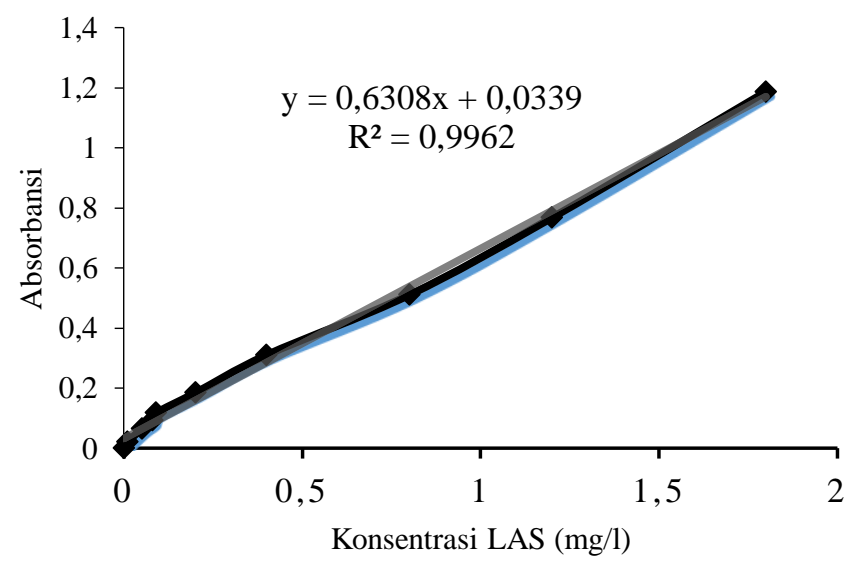

Gambar 4. Kurva kalibrasi LAS sebagai MBAS Sumber: Hasil Penelitian

\section{c. Pengolahan data}

Untuk mengolah data kualitatif digunakan 2 metode statistik yaitu metode statistik deskriptif dan metode statistik induktif. Metode statistik deskriptif yaitu metode yang dipakai untuk mengolah dan menyajikan data secara sistematis kedalam bentuk tabel atau grafik. Sedangkan metode statistik induktif (inferens) yaitu metode yang dipakai untuk menganalisa data antara lain dengan melakukan perkiraan, peramalan dan pengambilan keputusan berdasarkan data statistik yang diperoleh setelah melakukan penelitian. Analisa kuantitatif dilakukan dengan menggunakan analisa regresi dengan memakai software SPSS (Statistical Product and Service Solution) versi 23. Hasil Hipotesisnya adalah Ho: tidak ada pengaruh koagulan terhadap penurunan surfaktan dan kecepatan pengendapan flok dan H1: ada pengaruh koagulan terhadap penurunan surfaktan kecepatan pengendapan flok. 


\section{Hasil Dan Pembahasan}

\section{Pengaruh Koagulan PAC pada Penurunan Surfaktan Musim kemarau}

Berdasarkan Peraturan Pemerintah Republik Indonesia Nomor 82 Tahun 2001 Tentang Pengelolaan Kualitas Air dan Pengendalian Pencemaran Air bahwa kandungan maksimal deterjen adalah $200 \mu \mathrm{g} /$ liter. Dari hasil uji laboratorium terhadap parameter surfaktan pada musim kemarau menunjukkan bahwa hampir semua sungai tersebut mengalami pencemaran limbah deterjen, kecuali titik pengambilan sampel di Sungai Citarum Kalimalang. Hampir semua titik sampling air setelah melewati proses koagulasi konsentrasi surfaktan masih berada diatas standar baku mutu baik untuk air minum sesuai dengan Peraturan Menteri Kesehatan Republik Indonesia 492/MENKES/PER/IV/2010 Tentang Persyaratan Kualitas Air [18] yaitu nilai surfaktan adalah sebesar $0.05 \mathrm{mg} / \mathrm{l}$ dan Peraturan Pemerintah Republik Indonesia Nomor 82 Tahun 2001 Tentang Pengelolaan Kualitas Air dan Pengendalian Pencemaran Air, dimana nilai surfaktan sebesar $200 \mu \mathrm{g} / \mathrm{liter}$ [19].

Dari hasil penelitian lapangan memperlihatkan bahwa air sungai mengalami penyusutan yang cukup besar akan tetapi volume air limbah baik air limbah industri dan rumah tangga yang masuk ke sungai tetap seperti pada saat musim hujan. Menurut laporan BPLHD Provinsi Jawa Barat 2013-2018, berdasarkan hasil laporan kajian lingkungan hidup strategis (KLHS), bahwa telah terjadi degradasi mutu air sungai dan air permukaan karena buangan industri dan rumah tangga [20].

Surfaktan anionik adalah jenis yang sering dipakai karena biaya produksinya yang mudah dan murah. Surfaktan anionik yang umum digunakan adalah Linear Alkyl Benzene Sulfonates (LAS) contohnya Sodium Lauryl Sulphate adalah dari kelompok surfaktan anionik [21]. Penambahan koagulan PAC dalam proses koagulasi flokulasi dapat menurunkan nilai surfaktan Penurunan surfaktan setiap titik sampling diperoleh dengan menggunakan dosis optimum koagulan. Dalam penelitian ini penentuan dosis optimum dilakukan dengan perulangan minimal 3 kali dengan melihat bentuk flok yang besar dan cepat mengendap dengan tampilan supernatant bagian atas beker gelas yang paling jernih. Persentase penurunan surfaktan dapat dilihat pada Gambar 5.

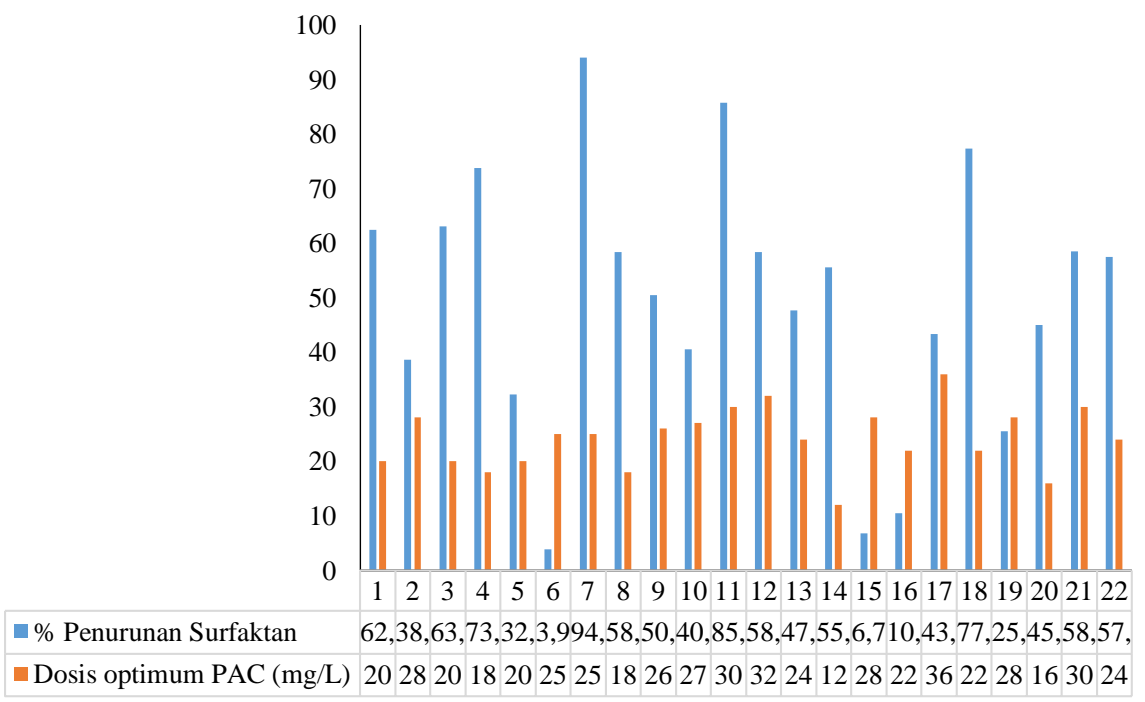

Gambar 5. Persentase Penurunan Surfaktan dengan dosis optimum koagulan PAC Sumber: Data penelitian

Gambar 5 terlihat bahwa persentase penurunan surfaktan dengan koagulan PAC bervariasi pada setiap sungai mulai 3,91\% - 94\% dengan rata-rata penurunan sebesar $49,51 \%$. Penurunan surfaktan terjadi karena koagulan PAC memiliki struktur molekul polimer dan benar-benar larut dalam air. Panjang rantai terpolimerisasi, berat molekul dan jumlah muatan ionik ditentukan oleh tingkat polimerisasi PAC saat diproduksi. Menurut ref. [22], ketika koagulan PAC diberikan dalam air sungai maka akan terjadi reaksi disosiasi dan hidrolisa, membentuk spesies polimer $\mathrm{Al}_{13} \mathrm{O}_{4}(\mathrm{OH})_{24}{ }^{7+}, \mathrm{Al}^{3+}, \mathrm{Al}_{13}{ }^{7+}$ dan $\mathrm{Al}(\mathrm{OH})_{3}$ yang sangat penting. Gambar 5 juga menunjukkan bahwa penurunan surfaktan setelah melalui proses koagulasi flokulasi, penurunan surfaktan ini terjadi melalui 4 tahap, yaitu destabilisasi partikel koloid, pembentukan mikroflok, penggabungan mikroflok, dan pembentukan makroflok [23, p. 173]. Surfaktan yang paling banyak dipergunakan dalam pembuatan deterjen adalah jenis anionic (Gambar 5), karena anionik maka 
jenis ini bermuatan negatif. Destabilisasi partikel koloid terjadi ketika produk hasil reaksi hidrolisa $\mathrm{Al}_{13}{ }^{7+}$ berintegrasi dengan partikel surfaktan bermuatan negatif yang terkandung dalam air sungai [24].

Penetralan atau destabilisasi muatan, menurut Ref. [25], merupakan interaksi langsung antara produk hidrolisis $\mathrm{Al}$ (III) yang bermuatan positif seperti $\mathrm{Al}^{3+}$ atau $\mathrm{Al}_{13}{ }^{7+}$ dengan partikel-partikel koloid bermuatan negative. Karena sifat surfaktan yang mampu meningkatkan kestabilan partikel yang terdispersi dan kemampuannya terserap pada minyak dan air untuk mencegah penggabungan koloid yang terurai [26]. Sehingga ketika ion $\mathrm{Al}^{3+}$ dari koagulan PAC terdispersi dalam air akan mengalami hambatan untuk medestabilisasikan surfaktan, karena ujung dari surfaktan yang bersifat hidrofobik akan menyerap ion $\mathrm{Al}^{3+}$.Selanjutnya senyawa hidroksida koagulan $\mathrm{PAC}$ dalam bentuk $\mathrm{Al}(\mathrm{OH})_{3}$ akan mengalami hal sama dengan ion $\mathrm{Al}^{3+}$. Hal ini yang menyebabkan koagulan PAC tidak memiliki pengaruh yang signifikan untuk menurunkan surfaktan dalam air sungai dalam proses koagulasi flokulasi.

Analisa kuantitatif dilakukan dengan uji statistik dengan menggunakan SPSS versi 23 dimana uji normalitas data berdistribusi normal. Hasil uji regresi tingkat signifikansi $\mathrm{F}=0,31$. Jika $\alpha=5 \%(0.05)$ maka didapat nilai sig $>\alpha$ jadi H0 diterima yang berarti destabilisasi surfaktan tidak dipengaruhi oleh koagulan tawas. Pada table regression-summary $\mathrm{R}^{2}$ didapat nilai 0.05 , ini berarti bahwa $5 \%$ penurunan surfaktan dapat dijelaskan karena destabilisasi surfaktan oleh proses koagulasi flokulasi, yaitu karena surfaktan yang terdapat di dalam air sungai merupakan partikel koloid yang bermuatan negatif dan akan dinetralkan oleh ion positif $\mathrm{Al}^{3+}$ atau $\mathrm{Al}_{13}{ }^{7+}$ dari koagulan PAC. Pada proses ini partikel koloid surfaktan telah mengalami proses destabilisasi. Selanjutnya, surfaktan yang telah mengalami destabilisasi akan diadsorpsi oleh senyawa $\mathrm{Al}(\mathrm{OH})_{3}$ yang berfungsi sebagai inti flok, pada tahap ini telah masuk pada proses pembentukan mikroflok. Dengan adanya pengadukan lambat mikrofok-mikroflok yang terbentuk akan mengalami penggabungan dan membentuk makroflok yang dapat mengendap secara grafitasi karena beratnya sendiri. Sedangkan 95\% karena kemampuan surfaktan sebagai senyawa aktif seperti dijelaskan diatas.

\section{Pengaruh Koagulan Aluminium Sulfat pada Penurunan Surfaktan dan Kecepatan Pengendapan Flok Pada Musim Kemarau}

Dari Gambar 6 terlihat bahwa persentase penurunan surfaktan dengan koagulan aluminium sulfat bervariasi pada setiap sungai mulai $5,71 \%-79,35 \%$ dengan rata-rata penurunan sebesar $31,10 \%$. Jika dibandingkan dengan koagulan PAC pada musim kemarau koagulan aluminium sulfat masih lebih kecil efisiensi penurunan surfaktannya. Hal ini disebabkan karena koagulan PAC adalah senyawa polimer aluminium sejenis aluminium sulfat yang mempunyai kandungan klorida, sedangkan koagulan aluminium sulfat bukan merupakan senyawa polimer. Saat aluminium sulfat ditambahkan ke dalam air sungai, kation Al pada aluminium sulfat akan mengalami serangkaian reaksi hidrolisis untuk membentuk spesies $\mathrm{Al}$ terlarut lainnya atau endapan aluminium hidroksida [27]. Spesies Al terlarut yang terbentuk tersebut berupa monomer dan karena beberapa di antaranya bermuatan positif dapat menetralkan atau mendestabilkan permukaan surfaktan yang bermuatan negatif sehingga memungkinkan terjadinya proses koagulasi. Ada 4 spesies $\mathrm{Al}$ yang terbentuk dalam reaksi hidrolisis aluminium sulfat, yaitu $\mathrm{Al}^{3+}$, $\mathrm{Al}(\mathrm{OH})^{2+}, \mathrm{Al}(\mathrm{OH})_{2}{ }^{+}$, dan $\mathrm{Al}(\mathrm{OH})_{4}{ }^{-}$. Implikasinya karena bukan senyawa polimer, kemampuan tawas untuk mereduksi surfaktan tidak sebaik koagulan PAC, hal ini dapat terlihat dari rata-rata persentase efisiensi penurunan surfaktan, dimana koagulan PAC lebih besar dari tawas.

Analisa kuantitatif menggunakan SPSS versi 23. Hasil uji regresi tingkat signifikansi $\mathrm{F}=1$,816.Jika $\alpha=5 \%(0.05)$ maka didapat nilai sig $>\alpha$ sehingga $\mathrm{H} 0$ diterima yang berarti destabilisasi surfaktan tidak dipengaruhi oleh koagulan tawas. Pada tabel regression-summary $\mathrm{R}^{2}$ didapat nilai 0,14 , ini berarti bahwa $14 \%$ penurunan surfaktan dapat dijelaskan karena destabilisasi surfaktan oleh proses koagulasi flokulasi. 


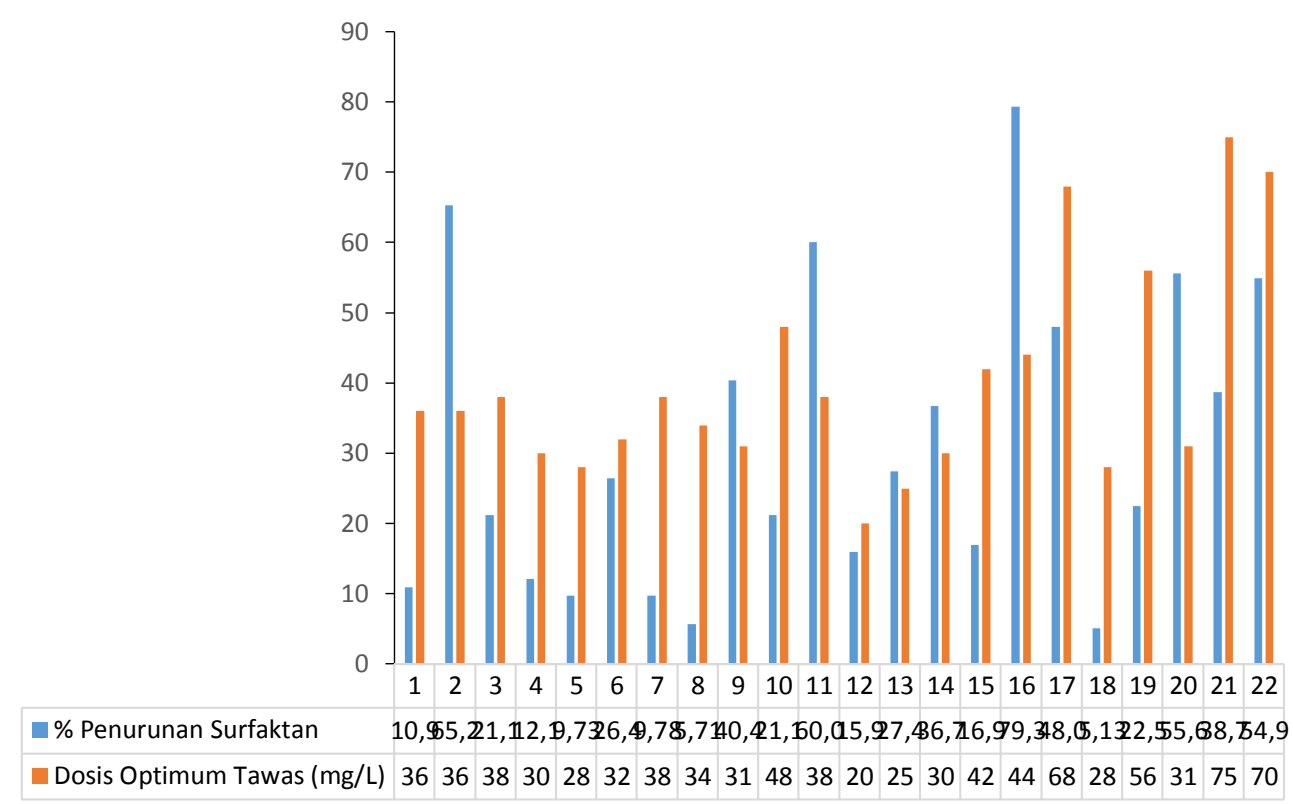

Gambar 6. Persentase Penurunan Surfaktan dengan dosis optimum koagulan Tawas pada musim kemarau Sumber: Data penelitian

Hubungan dari penjelasan bahwa persentase penurunan surfaktan dengan menggunakan koagulan PAC lebih besar dari koagulan tawas diperkuat dengan kecepatan pengendapan flok yang diperlihatkan pada Gambar 7.

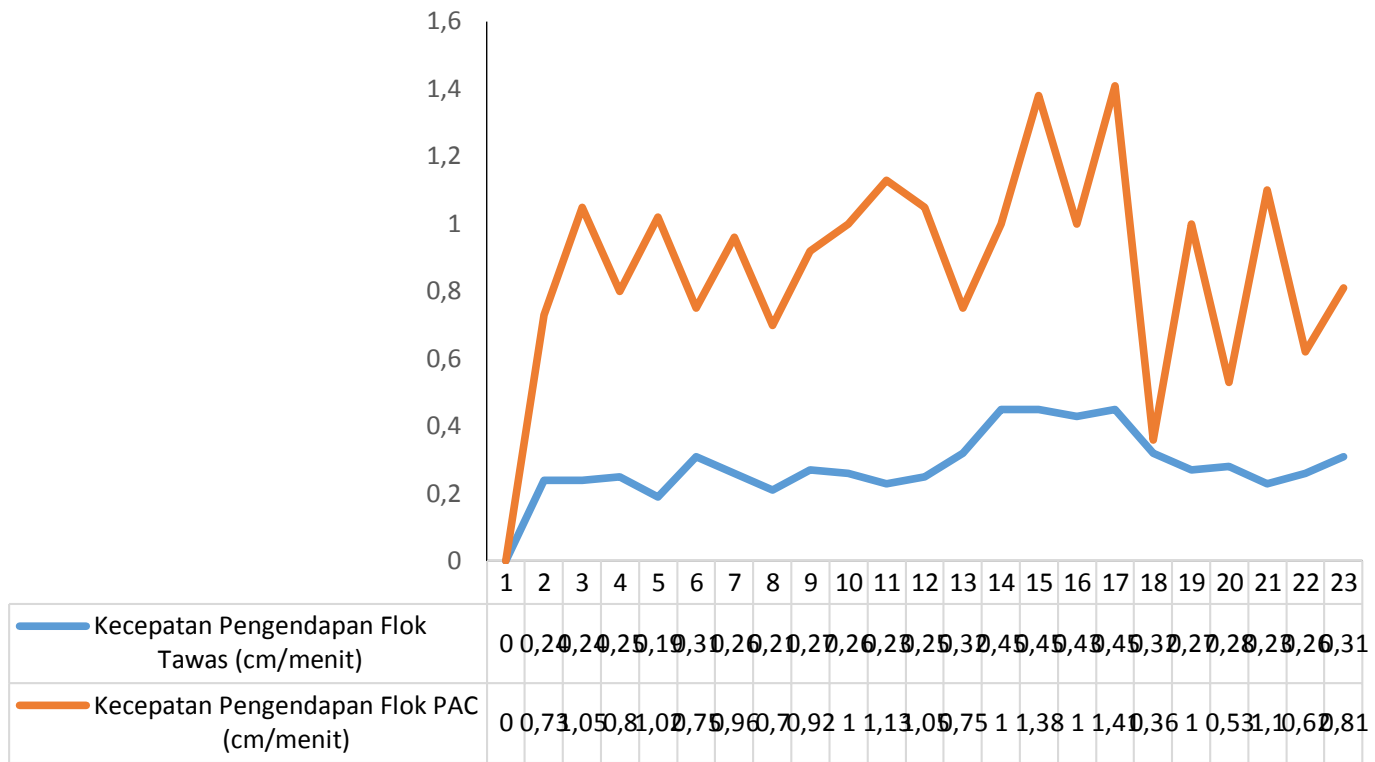

Gambar 7. Grafik Perbandingan Kecepatan pengendapan flok koagulan PAC dan Tawas pada musim Kemarau Sumber: Data penelitian

Berdasarkan grafik Gambar 7 menunjukkan bahwa kaogulan PAC memiliki kecepatan pengendapan yang lebih besar jika dibandingkan dengan koagulan tawas. Jika dirata-ratakan kecepatan pengendapan koagulan PAC sebesar 0,91 cm/menit dan koagulan tawas sebesar $0,30 \mathrm{~cm} / \mathrm{menit}$. Dari hasil pengamatan secara visual koagulan PAC membentuk makroflok lebih cepat dan besar dan segera mengendap dengan waktu pengendapan yang relatip cepat jika dibandingkan dengan koagulan tawas.

Selain itu korelasi penurunan Surfaktan dan kecepatan pengendapan flok pada air sungai adalah parameter surfaktan merupakan salah penyebab kekeruhaan air sungai dalam bentuk partikel koloid. Dengan adanya destabilisasi partikel koloid oleh koagulan dengan dosis yang optimum maka akan menghasilkan kecepatan pengendapan flok yang cepat, karena flok yang terbentuk berukuran besar. Dari 
hasil penelitian ini menunjukkan bahwa efisiensi penurunan terhadap surfaktan dengan proses ini masih belum maksimal, karena secara rata-rata masih dibawah $50 \%$.

\section{Pengaruh Koagulan Tawas pada Penurunan Surfaktan di Musim Hujan}

Dari hasil penelitian lapangan memperlihatkan bahwa air sungai mengalami tingkat kekeruhan yang tinggi dan sungai meluap jika terjadi hujan dengan intensitas yang tinggi. Hal ini menyebabkan walaupun air limbah industri dan rumah tangga masuk ke sungai akan mengalami pengenceran sehingga konsentrasi surfaktan dalam air sungai tidak terlalu besar jika dibandingkan dengan konsentrasi surfaktan pada musim kemarau yang sangat tinggi.

Jika dibandingkan dengan musim kemarau kebutuhan dosis koagulan tawas pada musim hujan lebih banyak. Sesuai teori koagulasi menyatakan bahwa semakin banyak partikel koloid penyebab kekeruhan maka akan semakin banyak membutuhkan koagulan untuk mendestabilkan partikel koloid. Hal ini sesuai dengan hasil penelitian [28] yang mejelaskan hubungan dosis koagulan dan tingkat kekeruhan yakni pada umumnya jumlah koagulan meningkat jika tingkat kekeruhan air juga mengalami kenaikkan tapi kenaikkan jumlah koagulan yang dipakai tidak harus linear dengan meningkatnya kekeruhan air. Gambar 8 menunjukkan bahwa penurunan surfaktan pada musim hujan dengan koagulan tawas bervariasi mulai dari 5,47\% sampai dengan 76,19\% dengan rata-rata penurunan surfaktan sebesar 40,73\%.



Gambar 8. Persentase Penurunan Surfaktan dengan dosis optimum koagulan Tawas pada musim hujan Sumber:Data Penelitian

Analisa kuantitatif dengan memakai SPSS versi 23. Hasil uji regresi tingkat signifikansi $\mathrm{F}=0,69$. Jika $\alpha=5 \%(0.05)$ maka nilai sig $>\alpha$ sehingga $\mathrm{H} 0$ diterima yang berarti destabilisasi surfaktan tidak dipengaruhi oleh koagulan tawas. Pada tabel regression-summary $\mathrm{R}^{2}$ didapat nilai 0,008 , ini berarti bahwa 0,8\% penurunan surfaktan dapat dijelaskan karena destabilisasi surfaktan oleh proses koagulasi flokulasi

\section{Pengaruh Koagulan PAC pada Penurunan Surfaktan dan Kecepatan Pengendapan Flok Pada Musim Hujan}

Dari Gambar 9 memperlihatkan bahwa persentase penurunan surfaktan dengan koagulan PAC bervariasi pada setiap sungai mulai 3,91\% sampai dengan 94\% dengan rata-rata penurunan sebesar 49,51\%. Jika dibandingkan dengan koagulan tawas penggunaan koagulan PAC dari 22 titik sampling lebih kecil, hal ini menunjukkan bahwa koagulan PAC lebih efektif dalam mereduksi surfaktan dalam air sungai. Demikian halnya dengan pemakaian koagulan terlihat bahwa pemakaian koagulan PAC lebih sedikit jika dibandingkan dengan koagulan tawas. Mekanisme penurunan surfaktan pada musim hujan dipengaruhi oleh tingkat pengenceran deterjen oleh air hujan dan meningkatnya kekeruhan air sungai oleh karena adanya lumpur hasil sedimentasi dari area tangkapan air hujan disekitar sungai. Tingkat kekeruhan air yang tinggi maka kebutuhan koagulan PAC akan meningkat.

Sama seperti pada musim kemarau mekanisme penurunan surfaktan oleh PAC pada musim hujan adalah Penetralan atau destabilisasi muatan, menurut ref. [25], merupakan interaksi langsung antara produk hidrolisis $\mathrm{Al}$ (III) yang bermuatan positif seperti $\mathrm{Al}^{3+}$ atau $\mathrm{Al}_{13}{ }^{7+}$ dengan partikel-partikel koloid bermuatan negative. Karena sifat surfaktan yang mampu meningkatkan kestabilan partikel yang 
terdispersi dan kemampuannya terserap pada minyak dan air untuk mengurangi atau menghambat penggabungan dari partikel yang terdispersi [26]. Sehingga ketika ion $\mathrm{Al}^{3+}$ dari koagulan PAC terdispersi dalam air akan mengalami hambatan untuk medestabilisasikan surfaktan, karena ujung dari surfaktan yang bersifat hidrofobik akan menyerap ion $\mathrm{Al}^{3+}$.Selanjutnya senyawa hidroksida koagulan PAC dalam bentuk $\mathrm{Al}(\mathrm{OH})_{3}$ akan mengalami hal sama dengan ion $\mathrm{Al}^{3+}$. Hal ini yang menyebabkan koagulan PAC tidak memiliki pengaruh yang signifikan untuk menurunkan surfaktan dalam air sungai dalam proses koagulasi flokulasi.

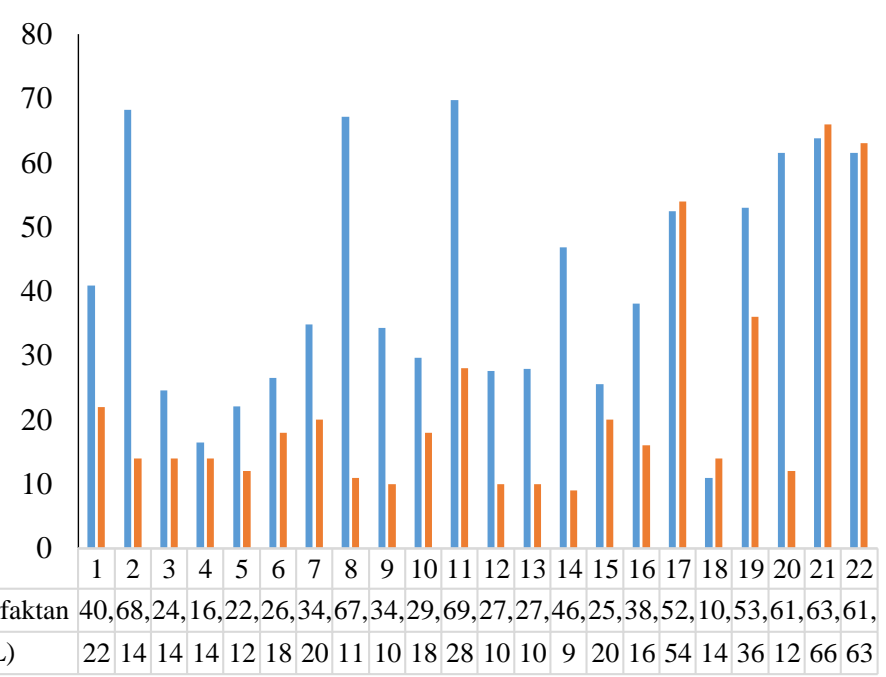

Gambar 9. Persentase penurunan Surfaktan dengan dosis optimum koagulan PAC pada musim hujan Sumber: Data penelitian

Hubungan dari penjelasan bahwa persentase penurunan surfaktan dengan menggunakan koagulan PAC lebih besar dari koagulan tawas diperkuat dengan kecepatan pengendapan flok yang diperlihatkan pada Gambar 10.



Gambar 10. Grafik Perbandingan Kecepatan pengendapan flok koagulan PAC dan Tawas pada musim Hujan Sumber: Data Penelitian

Berdasarkan Gambar 10 terlihat bahwa koagulan PAC memiliki kecepatan pengendapan yang lebih besar jika dibandingkan dengan koagulan tawas. Jika dirata-ratakan kecepatan pengendapan koagulan PAC sebesar $0,80 \mathrm{~cm} /$ menit dan koagulan tawas sebesar $0,27 \mathrm{~cm} / \mathrm{menit}$. Dari hasil pengamatan secara visual koagulan PAC membentuk makroflok lebih cepat dan besar dan segera mengendap dengan waktu pengendapan yang relatip cepat jika dibandingkan dengan koagulan tawas. Dari Gambar 10 juga 
memperlihatkan kecepatan pengendapan flok koagulan PAC dari 22 titik sampling air sungai lebih besar jika dibandingkan dengan koagulan tawas.

Analisa kuantitatif dilakukan dengan uji statistik dengan menggunakan SPSS versi 23. Hasil uji regresi tingkat signifikansi $\mathrm{F}=0,13$. Jika digunakan $\alpha=5 \%(0.05)$ maka diperoleh nilai sig $>\alpha$ sehingga menerima $\mathrm{HO}$ yang berarti destabilisasi surfaktan tidak dipengaruhi oleh koagulan PAC. Pada tabel regression-summary $\mathrm{R}^{2}$ didapat nilai 0,114 , ini berarti bahwa $11,4 \%$ penurunan surfaktan dapat dijelaskan karena destabilisasi surfaktan oleh proses koagulasi flokulasi.

\section{Kesimpulan}

Kesimpulan dari penelitian ini adalah bahwa koagulan PAC dan tawas tidak memiliki pengaruh terhadap surfaktan. Adapun penurunan surfaktan pada musim hujan untuk koagulan PAC sebesar 49,51\% dan koagulan tawas sebesar $40,73 \%$. Sedangkan pada musim kemarau penurunan surfaktan dengan koagulan PAC sebesar 41,06 \% dan koagulan tawas penurunan sebesar 31,10\%. Kemudian kecepatan pengendapan flok diukur untuk menjelaskan korelasi penurunan surfaktan, dan diperoleh hasil untuk musim hujan kecepatan pengendapan flok dengan koagulan PAC sebesar $0,80 \mathrm{~cm} / \mathrm{menit}$ dan tawas sebesar $0,27 \mathrm{~cm} /$ menit. Sedangkan pada musim kemarau dengan koagulan PAC kecepatan pengendapan floknya $0,91 \mathrm{~cm} /$ menit dan koagulan tawas sebesar $0,31 \mathrm{~cm} /$ menit. Hasil analisa kuantitatif regresi dengan uji statistik SPSS menunjukkan bahwa hipotesis H0 diterima yaitu koagulan tidak mempunyai pengaruh terhadap penurunan surfaktan. Dengan demikian keseluruhan proses koagulasi flokulasi dan sedimentasi belum mampu mereduksi konsentrasi surfaktan sesuai baku mutu lingkungan di Indonesia, sehingga perlu dilakukan proses pengolahan lanjutan dengan menggunakan alternatif pengolahan yang ada sesuai standar kualitas kebutuhan air.

5. Singkatan

BPLHD

BOD

COD

DAS

KLHS

LAS

PAC

PDAM

MBAS

SPSS
Badan Pengelolaan Lingkungan Hidup Daerah

Biochemical Oxygen Demand

Chemical Oxygen Demand

Daerah Aliran Sungai

Kajian Lingkungan Hidup Strategis

Linear Alkyl Sulfonat

Poly Aluminium Chloride

Perusahaan Daerah Air Minum

Metelyn Blue Active Surfactant

Statistical Product and Service Solution

\section{Referensi}

[1] P. J. B. Wahana Lingkungan Hidup, 'catatan Akhir Tahun Lingkungan Hidup Jawa Barat 2018', WALHI, 2018. https://walhi.or.id/catatan-akhir-tahun-lingkungan-hidup-jawa-barat-2018.

[2] BPS Propinsi Jawa Barat, "Jumlah Industri besar, Sedang dan Menengah di Propinsi Jawa Barat," BPS Propinsi Jawa Barat, 2018, Diakses pada Tanggal 9 September 2020 di https://jabar.bps.go.id/statictable/2016/1 1/11/148/jumlah-industri-besar-sedang-menurut-subsektorindustri-menurut-golongan-industri-di-jawa-barat-2010-2014.html.

[3] Dinas Lingkungan Hidup Propinsi Jawa Barat, "Status Mutu Sungai di 7 DAS Propinsi Jawa Barat," 2010, Accessed: Jun. 03, 2020. [Online]. Available: http://citarum.org/citarum-knowledge/pusatdatabase/data-tabular/kualitas-air/525-rangkuman-status-mutu-7-das/file.html.

[4] Chaerunisah dan R.N. Sopiah, "Laju Degradasi Surfaktan Linear Alkil Benzena Sulfonat (LAS) Pada Limbah Deterjen Secara Anaerob pada Reaktor Lekat Diam Biromedia Sarang Tawon," J. Teknol. Lingkung., vol. 7, no. 3, pp. 243-250, 2006.

[5] Johanna and U. Forsman, "Surfactants - What Are Their Differences?," Nyponros.com, 2016. https://nyponros.com/en/soap-and-other-surfactants/surfactants-differences.

[6] Z. Rahimah, H. Heldawati, and I. Syauqiah, "Pengolahan Limbah Deterjen Dengan Metode Koagulasi- Flokulasi Menggunakan Koagulan Kapur Dan Pac,” vol. 5, no. 2, p. 8, 2016.

[7] E. Susanti and A. Hartati, "Koagulasi Flokulasi Untuk Menurunkan Warna Dengan Koagulan Pac Pada Efluen Pengolahan Limbah Pencelupan Benang," p. 6, 2003.

[8] P. J. Delphos and G. M. Wesner, "Water Treatment Plant Design in Mixing, Coagulation, and Flocculation,” 4th ed., M. K. Kay, Ed. Virginia, California: McGraw-Hill, 2005, p. 107. 
[9] T. D. Reynolds and P. A. Richards, "Unit Operations and Processes In Environmental Engineering," 2nd ed., Boston: PWS Publishing Company, pp. 167-173, 1996.

[10] P. E. Prasetya and S. K. Saptomo, "Perbandingan Kebutuhan Koagulan $\mathrm{Al}_{2}(\mathrm{SO} 4) 3$ dan PAC Untuk Pengolahan Air Bersih di WTP Sungai Ciapus Kampus IPB Dramaga," Institut Pertanian Bogor, 2016.

[11] D. A. Christianty, B. Zaman, and Purwono, "Utilization of Seeds Durian (Durio Zibethinus Murr) Powder as Biopolymer Additional Materials of Coagulant Alum to Improve the Total Solids Removal Suspended (TSS) and COD using Leachate Coagulation-Flocculation," J. Tek. Lingkung., 2017.

[12] R. Yuni Kartika, "Keefektifan Dosis Koagulan Poly Aluminium Chloride (Pac) Dalam Menurunkan Kadar Total Suspended Solid (Tss) Air Limbah Laundry," 2015.

[13] J. Kaleta and M. Elektorowicz, "The removal of anionic surfactants from water in coagulation process," J. Environ. Technol., vol. 34, no. 8, pp. 999-1005, 2013, doi: DOI: 10.1080/09593330.2012.733415.

[14] S. Jangkorn, S. Kuhakaew, and S. Theantanoo, "Evaluation of reusing alum sludge for the coagulation of industrial wastewater containing mixed anionic surfactants," J. Environ. Sci., vol. 23, no. 4, pp. 587-594, doi: 10.1016/S1001-0742(10)60451-2, 2011.

[15] A. H. Mahvi, A.Maleki, and B.Roshani, "Removal Of Anionic Surfactants In Deterjent Wastewater by Chemical Coagulation," Pak. J. Biol. Sci., vol. 7, no. 12, pp. 2222-2226, 2004.

[16] W. P. Utomo et al., "Penurunan Kadar Surfaktan Anionik dan Fosfat dalam Air Limbah Laundry di Kawasan Keputih, Surabaya menggunakan Karbon Aktif," Akta Kim. Indonesia, vol. 3, no. 1, p. 127, Feb. 2018, doi: 10.12962/j25493736.v3i1.3528.

[17] Rodger, B. Baird, E. W.Rice, and S. Posavec, "Standard Methods for the Examination of Water and Wastewater," in 5540 Surfactants, 23rd ed., Washington: American Public Health Association, pp. 626-629, 2017.

[18] Kementerian Kesehatan RI, Peraturan Menteri Kesehatan Republik Indonesia Tentang Persyaratan Kualitas Air Minum. 2010, p. 7.

[19] Peraturan Pemerintah, Peraturan Pemerintah Republik Indonesia Nomor 82 Tahun 2001 Tentang Pengelolaan Kualitas Air Dan Pengendalian Pencemaran Air. 2001, p. 33.

[20] A. Sudarna, "Rencana Strategis BPLHD Provinsi Jawa Barat 2013-2018," Badan Pengelolaan Lingkungan Hidup, 2018. Accessed: Jun. 04, 2020. [Online]. Available: http://dlh.jabarprov.go.id/index.php/layanan/dokumen/kegiatan/renstra/tahun-2013-2018/53-renstra2013-2018-fix/file.

[21] N. Apriyani, "Penurunan Kadar Surfaktan dan Sulfat dalam Limbah Laundry," Media Ilm. Tek. Lingkung., vol. 2, no. 1, pp. 37-44, Feb. 2017, doi: 10.33084/mitl.v2i1.132.

[22] P. Gebbie, "Using Polyaluminium Coagulants In Water Treatment," p. 40, 2001.

[23] T. D. Reynolds and P. A.Richards, Unit Operation And Process In Environmental Engineering, Second edition., vol. 3, 3 vols. Boston: PWS Publishing Company, 1996.

[24] D. Alfa Christianty and Z. Zaman, "Utilization Of Seeds Durian (Durio Zibethinus Murr) Powder As Biopolymer Additional Materials Of Coagulant Alum To Improve The Total Solids Removal Suspended (Tss) And Cod Using Leachate," 2007.

[25] Y. Geng, "Application of Flocs Analysis for Coagulation Optimization at the Split Lake Water Treatment Plant," p. 108, 2005.

[26] M. J. Rosen, Surfactants and Interfacial Phenomena, 3rd Edition, 3rd ed. 2004.

[27] T. Singh, B. Parikh, and K. Pant, "Investigation on the sorption of aluminium in drinking water by low-cost adsorbents," Water SA, vol. 32, no. 1, pp. 49-54, Dec. 2007, doi: 10.4314/wsa.v32i1.5239.

[28] I. D. A. Sutapa, "Perbandingan Efisiensi Koagulan Poly Alumunium Chloride (PAC) Dan Alumunim Sulfat Dalam Menurunkan Turbiditas Air Gambut Dari Kabupaten Katingan Provinsi Kalimantan Tengah,” J. Ris. Geol. Dan Pertamb., vol. 24, no. 1, p. 98, 2005, doi: 10.14203/risetgeotam2014.v24.78. 